\title{
Urban Gardens as Sustainable Attractions for Children in Family Tourism
}

\author{
Francesc Fusté-Forné ${ }^{1, *(\mathbb{D})}$ and Maria Fusté Forné ${ }^{2}$ \\ 1 Department of Business, University of Girona, 17071 Girona, Spain \\ 2 Independent Researcher, 26006 Logroño, Spain; mariaff.education@gmail.com \\ * Correspondence: francesc.fusteforne@udg.edu or researchexperiencetourism@gmail.com
}

Citation: Fusté-Forné, F.; Forné, M.F.

Urban Gardens as Sustainable Attractions for Children in Family Tourism. Resources 2021, 10, 111. https://doi.org/10.3390/

resources10110111

Academic Editor: Farshid Aram

Received: 5 October 2021

Accepted: 29 October 2021

Published: 1 November 2021

Publisher's Note: MDPI stays neutral with regard to jurisdictional claims in published maps and institutional affiliations.

Copyright: () 2021 by the authors. Licensee MDPI, Basel, Switzerland. This article is an open access article distributed under the terms and conditions of the Creative Commons Attribution (CC BY) license (https:// creativecommons.org/licenses/by/ $4.0 /)$.

\begin{abstract}
Most of the global population live in urban environments and the majority of tourist flows are concentrated in cities. Urban agriculture has recently emerged as an avenue for the protection of sustainable food production and the promotion of sustainable food consumption. Also, the relationships between horticulture and tourism are attracting growing interest in the context of urban studies. Drawing on a qualitative approach based on ten semi-structured interviews, this research analyzes the relationship between urban gardens and family tourism. The paper innovatively contributes to the understanding of gardens as an urban attraction that improves the sustainable production and consumption of food in the context of family tourism experiences. The results show the relevance of urban gardens for the creation of sustainable experiences that engage families with local food, enhance local supply chains, and inform the future of urban environments. Urban gardens are a visitor attraction that may lead to the development of sustainable people, places and products, and they represent the sustainable integration of horticulture in tourism based on participatory experiences, direct contact with the natural environment and the discovery of the origin of food.
\end{abstract}

Keywords: food experience; horticultural tourism; urban agriculture

\section{Introduction}

According to the United Nations, more than half of the world's population live in cities and it is expected that more than two-thirds will live in urban areas by 2050 [1]. In this context, sustainable strategies are pivotal to guarantee this urban development, and urban agriculture, in particular, may lead to the planning and management of a sustainable urban food supply, thus "bringing positive impacts to local economics, environment, social equity and culture preservation" [2] (p. 1). Previous research defines urban agriculture as the production, processing and marketing of food within an urban environment [3-6]. Environmental threats caused by food production [7] compel cities to develop strategies that are based on sustainability. The effectiveness of urban agriculture relies on local-based food planning and its implementation reveals how the relationships between urban and rural spaces can be negotiated for the consecution of the UNESCO Sustainable Development Goals (SDGs) [8]. The proximity of food production is key to the development of "resilient, healthy and environmentally friendly city region food systems" [9] (p. 1). This transformation of food systems will also lead to sustainable food consumption, which also aligns with the Slow Food motto [10]. Previous studies have identified green spaces as a path to develop low-carbon tourism [11] and have also highlighted how its appreciation by locals and visitors develops sustainability in city environments [12]. While gardens in urban environments are growing globally [13], they are not yet integrated in urban sustainable development [14]. This research departs from the understanding of the relevance of gardens as urban spaces that are worthy of study from a tourism perspective in order to understand the role of a visit to an urban garden in enhancing the development of sustainable experiences from a family perspective. 
Recent research calls for the protection and promotion of sustainable food experiences, where the role of tourism in the regeneration of urban areas [15] is also acknowledged. "We need to redesign and rethink the very idea of the food experience with particular focus on participation, the role of the consumer, the accessibility of the food design, and the potential of local contexts", says Leer [16] (p. 65). The development of sustainable food experiences depends on participatory activities to develop a long-term strategy focused on both sustainable food production and consumption. Urban agriculture "has the potential to provide learning and education facilities for children and adult city-dwellers and help bridge the gap between consumers and producers" [17] (p. 43), which can also be achieved through tourism, and in particular, family tourism. This is the main contribution of this research, which investigates the educational role of community gardens as urban attractions from the perspective of families with children under six years old. As part of urban sustainable development [18], horticulture conveys a sense of community identity [19] and urban gardens emerge as an avenue to "exemplify their locale to the world" [20] (p. 371). While previous research reveals that horticulture may have an important role in tourism and acknowledges the impact of tourism on community development through horticulture [21], the linkages between horticulture and tourism are still underexplored [22]. This paper aims to fill this research gap and its scientific value is based on the relevance of urban gardens as a source of sustainable development that increases the awareness of travelers to urban destinations. Horticulture and tourism are two fields of research that demonstrate close human-nature relationships with a significant influence on community livelihoods [23]. This paper explores the bridge between urban gardens and family tourism as a path to develop the relevance of green spaces in cities and understand the benefits of urban gardens from a family perspective in a tourism system.

\section{Literature Review}

The theoretical section of the paper is divided into three parts. This structure reflects the development of a narrative that starts in Section 2.1, which reveals the relevance of urban agriculture as a path to develop green infrastructure in urban environments. This is exemplified through urban gardens. Later, Section 2.2 discusses the integration of horticulture in tourism experiences, and explains why an urban garden is placed as a tourism attraction that protects the values attached to local culture and nature, and acts as an educational driver. After that, Section 2.3 acknowledges the role of urban gardens in the promotion of sustainable futures in urban environments as areas with a projected growth in residents and visitors.

\subsection{An Approach to Urban Agriculture and Urban Gardens}

According to the Food and Agriculture Organization of the United Nations [24], urban agriculture refers to small production areas located within a city. Urban agriculture refers to "farming or gardening that takes place within and/or around cities" [4] (p. 291). Urban agriculture "is an industry located within (intraurban) or on the fringe (periurban) of a town, a city or a metropolis, which grows or raises, processes and distributes a diversity of food and non-food products, (re-)using largely human and material resources, products and services found in and around that urban area, and in turn supplying human and material resources, products and services largely to that urban area" [5] (p. 10). According to previous research, urban agriculture fosters quality of life [19], urban-rural relationships [2], and improves community development and green infrastructure [12]. Also, the knowledge of hosting communities about the local culture and environment, and local traditions, is a driver for the development of livelihood sustainability [23]. Uniyal et al. [25] highlight that the increasing significance of sustainability suggests the need "to improve the efficiency of value chain activities" (p. 164), which include the processes from production to consumption. There are different types of urban agriculture models, such as home gardens, commercial farms, and urban parks [26], community, private and 
rooftop gardens [27], greenhouse farming [28] and vertical farming [29,30]. This research is particularly interested in the study of urban gardens.

From a historical perspective, urban gardens have been part of the urban landscape. However, it was not until the second half of the 20th century that they started to attract attention as an avenue to improve the residents' quality of life, primarily through quality food products [31]. The development of ecological activities is part of urban regeneration [32], which leads to environmental, economic and social transformation. Chen et al. [33] report that "social concerns and waste minimization perspectives contribute the most to the sustainable consumption model in which the criteria such as consumers' sustainable issue interest, responsible waste disposal and health-based products play a major role in influencing consumer willingness-to-pay" (p. 1). According to recent research, urban agriculture is an activity that provides social meaning to agricultural practices [34], and places "food" as a source of city identity [35]. A tourism value can be awarded later to urban agriculture venues [36].

In relation to the typologies of urban gardens, Zhao et al. [37] identify four landscapes based on different objectives: modern commercial, cultural heritage, historical preservation and natural areas. In particular, natural spaces are highly preferred by residents, who appreciate "urban gardens without artificial transformation and prioritized the maintenance of natural landscaping and the historical and cultural heritage of urban gardens" (p. 1). In addition, Zhao et al. [37] also report that in order for urban gardens to be incorporated to a tourism system, both the cultural and historical values must be promoted to encourage a heritage-based tourist experience in green environments. In a similar vein, previous studies have developed the understanding of urban gardens not only as a relevant social space, but also as an example of a leisure and entertainment resource, which, drawing from the agricultural tradition, can become a tourist attraction [38]. Gardens are important tourist attractions [39], and urban gardens [12] are an especially relevant landmark in the development of knowledge about food heritage, to protect local and traditional foods, and also to promote local food-based activities. For example, a Persian garden "is formed by the interactions between Iranian society and their environment. Therefore, it would be a suitable case for examining the role of food in its tourist attraction and tourism perception" [40] (p. 282).

\subsection{The Integration of Horticulture in Tourism Experiences}

As mentioned above, the relationships between horticulture and tourism allow us to understand human-nature relationships [19,41]. Horticultural tourism is "a niche market in green tourism and describes the benefits and potential of the green assets, such as public parks and recreation facilities, historic and heritage gardens, national and international horticultural events, rural farm visits, community gardens and farmers markets" [19] (p. 55). Previous work has suggested that the local origin of fruits and vegetables supplied by farmers are of crucial importance in the development of the relationship between horticulture and tourism [22]. In this sense, green spaces in urban environments are key in urban policy [42]. The nature-based environments found in urban areas are understood as "urban green spaces" [14] that have a direct impact on both health and wellbeing. Urban gardens have emerged as an example of urban green spaces that "are able to offer answers to renewed food, environmental and socio-cultural needs. They can therefore be an important instrument for the integration between building renovation and natural and agricultural environments and could contribute to reducing the vulnerability of the urban system" [14] (p. 285). Urban agriculture shapes sustainable cities $[43,44]$ in the transition towards a bioeconomy [45].

In addition, education emerges as an important pathway to show people the value of horticulture and plant cultivation [21] and to improve the ecological and social benefits of horticulture. From the perspective of education in a family context, and specifically, during the early childhood stages, this paper follows previous work to further develop the understanding of food values in families with children under six years old. Langemeyer 
et al. [46] studied the values of urban gardens in Barcelona and indicated "a correlation between childhood experiences and stewardship action". The objective of this article is to analyze the relationships between urban gardens and family tourism to discover how families observe urban gardens in the context of learning and leisure experiences while traveling. This is translated into the research question of how and why urban gardens contribute to sustainable practices within the framework of family tourism.

Previous research has also identified the relevance of urban gardens as education facilities in the context of food production and consumption experiences. According to Specht et al. [17], "a number of existing projects demonstrate how farming activities can serve as showcases for education on food production. Famous examples include the Science Barge, an urban greenhouse and educational center that grows vegetables in New York City and is visited by school classes and thousands of visitors throughout the year" (p. 44). It is located in Yonkers, next to the Hudson River and 15 miles from the city center. This demonstrates that urban gardens do not only improve the resilience of urban environments [3], but they also contribute to the provision of services both to residents, for example, through landscape maintenance [47], and to visitors, for example, through tourism products [48].

\subsection{Urban Gardens towards Sustainable Urban Futures}

Are there experiences aimed at urban and rural linkages that work towards the sustainability of food production and consumption? Urban gardens are an example of equilibrated relationships between rural and urban areas [49], where "cities are increasingly taking the lead in the food system transition with a focus on city-region-based food provision" [9] (p. 1). In this sense, local food consumption is crucial in tourism [50,51], and it greatly influences tourist experiences $[52,53]$. Within the intersection between horticulture and tourism, "local food experiences can become strong linkages between tourism and local horticultural production" [41] (p. 136). Also, urban gardens can lead to a growing tourist consumption of local food, which contributes to the prosperity of urban areas [12] and enhances the quality of life of communities and visitors [19].

In addition, Muñoz [54] highlights the benefits of urban gardens, which are economic (for example, they support local food supply chains), educational (for example, discovery of healthy food habits), environmental (for example, sustainable use of resources), and social (for example, collaborative work). Among the services offered by urban gardens (see [55]), they provide knowledge about cultural services (for example, environmental education, neighborhood identity or intergenerational relationships), food supply (for example, the quality of food, types of food or the origin of food), and regeneration since they contribute to the local economy, local environment and local spaces.

While previous research reveals that the presence of urban gardens in urban areas is still scarce [38], chefs and luxury restaurants have recently started to pay more attention to the production of their own raw food in order to offer a value-added menu that relies on a genuine locally grown food. This type of initiative has experienced success in European countries such as Spain [56], for example, the urban garden of the Wellington Hotel in Madrid [57], which is located in Velázquez Street in the central Salamanca neighborhood. The growth of urban agriculture in general and of urban gardens in particular, has broadened the participation of different stakeholders, who are no longer just those who design the spaces and promote their value [58], but also those who protect urban gardens as spaces to valorize the public space of the city and to attract tourism [55].

\section{Methods}

Following the work of Khatami et al. [40], who analyzed gardens from the perspective of local foods, this research studies urban gardens and their connection to family tourism [59,60], which is a growing niche market relevant to the future of tourism [61]. This research aims to investigate how horticultural tourism is a source of family experiences, and may contribute to the configuration of sustainable food production and consumption 
in a tourism system. Nowadays, "the paradox of modern society is that a general interest in following an environmentally friendly lifestyle is accompanied by a loss of contact with the natural world" [42] (p. 306). In this sense, green areas in urban environments respond to the demand of people who seek a balance between "rush" and "relax", which has been accelerated by the spread of COVID-19 [62]. Regions has rapidly developed sustainable strategies to enhance responsible leisure and tourism close to home [63].

This research is based on a qualitative design that is focused on semi-structured interviews [64]. Interviews are recommended in qualitative research [65] to understand a particular topic [66]. Interviews are useful for developing a dialogue between the interviewers and the interviewees, which leads to the construction of a narrative around the topic of study [67]. A non-probability convenience sampling method was used to identify the participants [68] who were required to meet two criteria in order to discuss the role of urban gardens from a family tourism perspective: to live in an urban environment and travel frequently to urban spaces, and to have at least one child under six years old because the age of children is considered as an important factor in family vacations $[69,70]$ and the age range from 0 to 6 is considered as the stage when children adopt food habits and preferences [71]. In addition, previous research states that "in preschool education the process of preparing a child for the future role of a tourist is of great importance. The way attitude towards tourism and the knowledge of local history is shaped in kindergarten, will decide upon intensity and value of adult generations' tourism" [72] (p. 75). The interviews were performed online during the month of June 2021 with Spanish families, and a theoretical saturation was reached after ten interviews because no new information was emerging from the interviews [73]. Table 1 shows the profile of the participants. After the interviews were conducted, a thematic analysis [74] was carried out in order to identify why urban gardens are a visitor attraction that can develop sustainable family tourism.

Table 1. Profile of the participants.

\begin{tabular}{cccc}
\hline Interviewee & Gender & Age Range & Number of Children \\
\hline 1 & Female & In her forties & 2 \\
2 & Female & In her twenties & 2 \\
3 & Male & In his thirties & 3 \\
4 & Female & In her thirties & 3 \\
5 & Female & In her thirties & 1 \\
6 & Male & In his forties & 2 \\
7 & Male & In his forties & 3 \\
8 & Female & In her thirties & 3 \\
9 & Female & In her twenties & 1 \\
10 & Male & In his thirties & 2 \\
\hline
\end{tabular}

\section{Results}

This section is divided into three different sub sections that explore why an urban garden is a family tourism-driven attraction, and how the urban garden activities and experiences are useful for children with regards to the future sustainable development of cities in the context of horticultural tourism.

\subsection{Urban Gardens and Their Attraction in Family Leisure}

All the participants agreed on the importance of urban gardens for the morphology of a sustainable city, and also to protect and promote local products. Most of the interviewees noted that urban gardens help children to discover where fruits and vegetables come from. In addition, these products are organic, and they are designed for local consumption and encourage people to eat a healthier diet. One participant pointed out that urban gardens also allow learning in a direct and participatory way "because they can learn new things and they can enjoy a lot!" and another participant reported that "they can learn about plants, take care of other living beings and do some tasks that they are not used to". In a 
similar vein, one of the interviewees observed that urban gardens stimulate the different senses in order to "appreciate different plants, discover new smells and touches... and know the plants and trees that they will see later outside". These aspects can facilitate the sensitivity of future generations towards the environment.

In this sense, one of the participants summarized the main attraction factors of urban gardens, not only as a tourist experience, but also their use in people's day-to-day life. Urban gardens serve "to show people the source of food, how to take care of the land, improve their predisposition to eat vegetables, have more contact with the natural environment in their own city". The presence of the "rural" in the "urban" was also valued by another interviewee who highlighted its importance in the following way: "because you see the fruits and the vegetables that you eat, and children must know the products do not come from the shelves of groceries and supermarkets". Agriculture is the source of food and, consequently, of the experiences of horticultural tourism.

\subsection{Horticultural Tourism Experiences in Urban Gardens}

In relation to experiences that can encourage family learning and at the same time strengthen the sustainability of food systems in urban environments, the interviewees highlighted activities in two directions. The first was the significance of direct contact with food and plants. "Children can plant a fruit, water the plants, collect some vegetables" are some of the activities proposed to help connect people with both food and the land, generating a positive experience for all those involved. This may result in children being more predisposed to consume healthy foods, and improving their diet by developing healthier food habits and preferences. Depending on the age of the children, it is interesting to offer "explanations of the different plants and how they grow, how they are cultivated and how they are harvested". Another significant element is the time when they grow because fruits and vegetables always rely on seasonality. In addition, an interviewee remembered an experience at home: "we have a strawberry plant, and my son really enjoys to water it, take care of it, and eat the strawberries!". This shows the value chain from seeding to consumption, children being aware of the different stages and stimulating their interest in the origins of food.

Second, in addition to being able to observe the most common foods, urban gardens also display a variety of fruits and vegetables, and plants, which introduces children to the context of sustainable nutrition and highlights the importance of consuming locally grown products. As a consequence, this also contributes to the future development of sustainable cities with a slower pace, without the usual rush of daily life in cities. In relation to consumption, some of the interviewees pointed out the importance of being able to taste the products. After planting and watering them, the experience must include eating them. "To harvest the products and then prepare a simple recipe with the family and taste them", is a dynamic way of encouraging learning in the context of a food experience, both as a daily practice and as part of horticultural tourism.

\subsection{Learning Outcomes for Next Generation of Sustainable Citizens and Tourists}

A factor that was repeated regularly in the interviews refers to the values that urban gardens can convey to children. The main value is respect for nature and appreciation of the natural environment. "Learn to take care of the vegetables and the development of the vegetables: planting, watering, harvesting... and have fun", stated one of the participants. Several interviewees also highlighted the values of patience and responsibility that are embedded in the cultivation process. All these factors have an impact on the development of skills and the promotion of sustainable values among children. From their knowledge of food production, children can learn the life cycle of the food they eat. It is important to "learn about nature and the environment in which they live and explain the perseverance of the growers, which is something that will be useful for them in their future". This same interviewee affirmed that "it is vital that young people are aware of the significance of the land and people who work to source the cities. Agriculture is a basic activity for all 
humanity and some people think that chickens do not have plumes", as a consequence of a lifestyle that is too urbanized and has little contact with the environment.

Another outstanding value of urban gardens is their role in encouraging a positive attitude towards the protection of the environment and the promotion of a healthier diet, as mentioned earlier. They provide a sensory experience; one interviewee emphasized that "my son really like to visit a garden, he asks about different vegetables and what they are used for, and at the same time we talk about smells and tastes and whether he likes them or not...". In this sense, not only psychomotor and social skills are developed, but also self-consumption and self-sufficiency. Furthermore, urban gardens are also a driver for understanding the value of local supply and seasonal foods, which is not only a symbol of respect for sustainable production, but it also creates the habit of sustainable consumption and production in children and their families, which contributes to an improvement in urban development and the sustainability of cities.

\section{Discussion and Conclusions}

Urban gardens contribute to health promotion and community development [75], and as part of urban agriculture, they play a strategic role in urban regeneration [76]. This research provides an understanding of the value of urban gardens for families with children under six years old, in the context of horticultural experiences that protect and promote local food. According to Leer [16], local food experiences need to inspire people to understand eating practices "that are sustainable not only in terms of climate, but also in cultural, social and economic terms" (p. 66). In this sense, green spaces provide a sense of place attachment [77] and urban gardens provide a sustainable food experience in urban areas. In the context of the relationships between horticulture and tourism, Figure 1 shows the summary of our findings. Cities continue to be not only the most popular environment in which to live, but also to visit [78]. Horticultural tourism is a growing niche tourism market and it is specifically based on "the principles and practices associated with sustainable development, with minimal impact on the environment, promotes health and active living, and is supportive of local culture and economy" [19] (p. 55). According to Forleo and Benedetto [49], the relationships between people, places and products are pivotal in promoting the significance of "food" as a creative experience in natural environments (see also [19]).

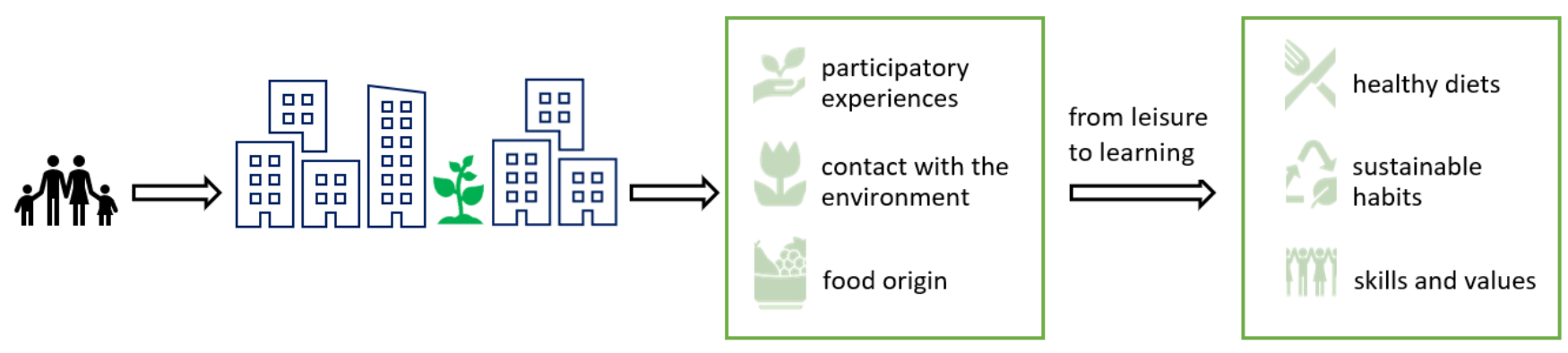

Figure 1. The role of family tourism in urban gardens.

Urban gardens are an intergenerational meeting point, and given the current global world, also interracial [79]. They represent a link between generations and cultures. According to Specht et al. [17], the social advantages of urban gardens rely on "improving community food security, the provision of educational facilities, linking consumers to food production, and serving as a design inspiration" (p. 49). Previous studies also understand urban gardens as a tool for environmental education among residents and visitors [55], as is stated in this paper. Urban gardens make cities more resilient [80] and focused on the protection and promotion of place identity and social cohesion [46].

Urban agriculture activities and practices emerge as a means of providing urban centers with local food [2] in order to mitigate food risks derived from global crises such as climate change and supply shortages [9], and reduce the impact of transport emissions [17]. 
Urban gardens as an example of urban agriculture also improve the eating habits of children [81] as sophisticated consumers who want to emulate the habits of adults [61]. In this sense, sustainable urban food policies should focus on the protection of local production of organic food, the promotion of urban agricultural landscapes, and the support of local stakeholders and supply chains. It is crucial to engage consumers with local food and show them how to access local quality food [82]. In addition, urban gardens contribute to the preservation of local ecological knowledge and increase the quality of life in cities [55]. In this framework, a collaboration between urban gardens, markets and restaurants can create additional value to food production [83] and further cooperation with public stakeholders can bring local food products directly to urban consumers [84] and urban tourists [85].

Do urban gardens reinforce the rural-urban relationship and the consecution of SDGs? Previous research states that "focusing on locally produced products can result in benefits for both hosts and guests. In the first instance, increasing tourist consumption of local foods can generate a multiplier effect that will benefit the local economy" [41] (p. 137). This study adds texture to recent conversations that explore the role of local food in urban environments in the context of tourism [86]. Previous research has also reported that the development of green infrastructure may develop "an iconic tourism attraction that highlights sustainability and celebrates biodiversity" [12] (p. 6). Urban gardens represent a way to "relieve the pressure of the urban landscape while assuming a sustainable ecological management of green spaces" [79] (p. 408), which is challenging because the management and marketing of urban gardens must consider economic, environmental and social variables [14].

In the context of the SDGs, number 11 advocates for sustainable cities and communities in order to "make cities inclusive, safe, resilient and sustainable" [8]. Urban gardens contribute to the achievement of this goal. When cities integrate horticulture into leisure and tourism, the relevance of urban gardens is observed (Figure 1). As exemplified in this research, the perspectives of families reveal that urban gardens must develop participatory experiences that allow children to have direct contact with the natural environment and the origin of food. This encourages healthy diets that promote sustainable food production and consumption, which must be an ingredient in green marketing [87]. Also, urban gardens are a leisure and tourist experience that delivers a learning opportunity to develop skills and values, and sustainable habits for the future.

Finally, this paper's main limitation is its qualitative design, which relies on a relatively small sample of families. This certainly needs further study from a quantitative perspective, which would provide more representative results. In this sense, while the results of this research are not generalizable, they set a research direction to further explore the relationships between horticulture and tourism. The results provide information about urban gardens in relation to the management and marketing of horticultural experiences. Also, they inform families about the role of urban gardens in sustainable production and consumption, and sustainable urban environments. In the specific framework of urban agriculture, urban gardens represent a sustainable attraction where more research is required from the perspectives of the different stakeholders. This will provide a deeper understanding of the sustainable relationships between people (families who travel), places (cities who host urban garden experiences) and products (local food).

Author Contributions: Conceptualization, F.F.-F. and M.F.F.; methodology, F.F.-F. and M.F.F.; formal analysis, F.F.-F. and M.F.F.; writing, F.F.-F. and M.F.F. All authors have read and agreed to the published version of the manuscript.

Funding: This research received no external funding.

Institutional Review Board Statement: Not applicable.

Informed Consent Statement: Informed consent was obtained from all participants.

Data Availability Statement: Data are contained within the article.

Acknowledgments: The authors acknowledge the availability of the interviewees. 
Conflicts of Interest: The authors declare no conflict of interest.

\section{References}

1. United Nations. The World's Cities in 2018; United Nations: New York, NY, USA, 2018.

2. Wang, N.; Zhu, L.; Bing, Y.; Chen, L.; Fei, S. Assessment of urban agriculture for evidence-based food planning: A case study in Chengdu, China. Sustainability 2021, 13, 3234. [CrossRef]

3. De Zeeuw, H.; Van Veenhuizen, R.; Dubbeling, M. The role of urban agriculture in building resilient cities in developing countries. J. Agric. Sci. 2011, 149, 153-163. [CrossRef]

4. Luehr, G.; Glaros, A.; Si, Z.; Scott, S. Urban agriculture in Chinese cities: Practices, motivations and challenges. In Urban Food Democracy and Governance in North and South; Palgrave Macmillan: London, UK, 2020; pp. 291-309.

5. Mougeot, L.J. Urban agriculture: Definition, presence, potentials and risks. Grow. Cities Grow. Food Urban Agric. Policy Agenda $2000,1,42$

6. Smit, J.; Nasr, J.; Ratta, A. Urban Agriculture: Food, Jobs and Sustainable Cities; United Nations Development Programme: New York, NY, USA, 1996.

7. Rodrigues, P.B. The Prospect of Permaculture as a Part of Gastronomic Tourism in New Zealand; Auckland University of Technology: Auckland, New Zealand, 2021.

8. UNESCO. UNESCO and Sustainable Development Goals. 2020. Available online: https://en.unesco.org/sustainabledevelopmentgoals (accessed on 1 February 2021).

9. Van der Gaast, K.; van Leeuwen, E.; Wertheim-Heck, S. City-Region Food Systems and Second Tier Cities: From Garden Cities to Garden Regions. Sustainability 2020, 12, 2532. [CrossRef]

10. Kowalczyk, A. New Trends in Gastronomy in the Context of the Urban Space. In Gastronomy and Urban Space: Changes and Challenges in Geographical Perspective; Kowalczyk, A., Derek, M., Eds.; Springer Nature: Cham, Switzerland, 2020.

11. Kusakabe, K.; Shrestha, P.; Kumar, S.; Nguyen, K.L. Pathways to sustainable urban tourism: Garden houses in Hue, Vietnam. Int. J. Sustain. Soc. 2015, 7, 286-303. [CrossRef]

12. Newsome, D. Sustainability can start with a garden! Int. J. Tour. Cities 2020, 24, 1-8. [CrossRef]

13. Henley, J. The Future of Food: Inside the World's Largest Urban Farm-Built on a Rooftop. 2020. Available online: https:/ /www. theguardian.com/cities/2020/jul/08/the-future-of-food-inside-the-worlds-largest-urban-farm-built-on-a-rooftop (accessed on 1 February 2021).

14. Sturiale, L.; Scuderi, A.; Timpanaro, G.; Foti, V.T.; Stella, G. Social and Inclusive "Value" Generation in Metropolitan Area with the "Urban Gardens" Planning. In Values and Functions for Future Cities. Green Energy and Technology; Mondini, G., Oppio, A., Stanghellini, S., Bottero, M., Abastante, F., Eds.; Springer: Cham, Switzerland, 2020; pp. 285-302.

15. Owen, C. Tourism and urban regeneration. Cities 1990, 7, 194-201. [CrossRef]

16. Leer, J. Designing sustainable food experiences: Rethinking sustainable food tourism. Int. J. Food Des. 2020, 5, 65-82.

17. Specht, K.; Siebert, R.; Hartmann, I.; Freisinger, U.B.; Sawicka, M.; Werner, A.; Thomaier, S.; Henckel, D.; Walk, H.; Dierich, A. Urban agriculture of the future: An overview of sustainability aspects of food production in and on buildings. Agric. Hum. Values 2014, 31, 33-51. [CrossRef]

18. Mercer, C. Cultural Planning for Urban Development and Creative Cities. 2006. Available online: http://www.kulturplanoresund.dk/pdf/Shanghai_cultural_planning_paper.pdf (accessed on 1 February 2021).

19. Aldous, D.E. Integrating horticulture into the tourism supply chain. In Proceedings of the IV International Conference on Landscape and Urban Horticulture 1181, Kolkata, India, 12 September 2013; pp. 55-68.

20. Khoo, S.L.; Badarulzaman, N. Factors determining George Town as a city of gastronomy. Tour. Plan. Dev. 2014, 11, 371-386. [CrossRef]

21. Relf, P.D. Horticulture and Tourism: Identifying Research Needs. In XI International People Plant Symposium on Diversity: Towards a New Vision of Nature 1093; International Society for Horticultural Science: Baarlo, The Netherlands, 2012; pp. 117-124.

22. Abdalla, J.O.; Bengesi, K.M. Factors Influencing Tourism-Horticulture Linkage among Smallholder Farmers in Zanzibar. Int. J. Humanit. Soc. Sci. 2018, 8, 105-113. [CrossRef]

23. Su, M.; Sun, Y.; Min, Q.; Jiao, W. A community livelihood approach to agricultural heritage system conservation and tourism development: Xuanhua Grape Garden urban agricultural heritage site, Hebei Province of China. Sustainability $2018,10,361$. [CrossRef]

24. FAO. El estado Mundial de la Agricultura y la Alimentación; FAO: Rome, Italy, 1996.

25. Uniyal, S.; Mangla, S.K.; Sarma, P.R.; Tseng, M.L.; Patil, P. ICT as "Knowledge management” for assessing sustainable consumption and production in supply chains. J. Glob. Inf. Manag. 2021, 29, 164-198. [CrossRef]

26. Wadumestrige Dona, C.G.; Mohan, G.; Fukushi, K. Promoting Urban Agriculture and Its Opportunities and Challenges-A Global Review. Sustainability 2021, 13, 9609. [CrossRef]

27. Lin, B.B.; Philpott, S.M.; Jha, S. The future of urban agriculture and biodiversity-ecosystem services: Challenges and next steps. Basic Appl. Ecol. 2015, 16, 189-201. [CrossRef]

28. Redmond, R.S.; Fatemeh, K.; Ting, K.C.; Thorp, K.R.; Hameed, I.A.; Weltzien, C.; Ahmad, D.; Shad, Z.M. Advances in greenhouse automation and controlled environment agriculture: A transition to plant factories and urban agriculture. Int. J. Agric. Biol. Eng. $2018,11,1-22$. 
29. Milestad, R.; Carlsson-Kanyama, A.; Schaffer, C. The Högdalen urban farm: A real case assessment of sustainability attributes. Food Secur. 2020, 12, 1461-1475. [CrossRef]

30. Son, J.E.; Kim, H.J.; Ahn, T.I. Plant Factory. An Indoor Vertical Farming System for Efficient Quality Food Production; Academic Press: London, UK, 2020.

31. Fantini, A. Cultivando Ciudades. La Agricultura Urbana y Periurbana Como Práctica de Transformación Territorial, Económica, Social y Política. 2016. Available online: https://www.educacion.gob.es/teseo/imprimirFicheroTesis.do?idFichero=OcZ6 cSfFzeM\%3D (accessed on 1 February 2021).

32. Zaar, M.-H. Agricultura urbana: Algunas reflexiones sobre su origen e importancia actual. Biblio. Rev. Bibliográfica Geogr. Cienc. Soc. 2011, 16, 944.

33. Chen, C.C.; Sujanto, R.Y.; Tseng, M.L.; Fujii, M.; Lim, M.K. Sustainable consumption transition model: Social concerns and waste minimization under willingness-to-pay in Indonesian food industry. Resour. Conserv. Recycl. 2021, 170, 105590. [CrossRef]

34. Larrubia Vargas, R.; Natera Rivas, J.J.; Carruana Herrera, D. Urban gardens as an urban transition strategy for the sustainability in the city of Málaga. Boletín Asociación Geógrafos Españoles 2020, 86, 1-55.

35. Schiavo, C.A. Empoderamiento y acción colectiva en producciones agroalimentarias con identidad territorial. Pampa Revista Interuniversitaria Estudios Territoriales 2009, 5, 9-50.

36. Gómez Sal, A.; González García, A.; Doña, H. La cultura del patio como soporte de agricultura familiar en América tropical. Ambienta Revista Ministerio Medio Ambiente 2014, 107, 74-85.

37. Zhao, Z.; Wang, Y.; Hou, Y. Residents' spatial perceptions of urban gardens based on soundscape and landscape differences. Sustainability 2020, 12, 6809. [CrossRef]

38. Fernández Santamaría, C. Huertos Urbanos Municipio Alicante: Importancia Contribución Territorio Sociedad; Universidad de Alicante: Alicante, Spain, 2017.

39. Paiva, P.D.D.O.; Sousa, R.D.B.; Carcaud, N. Flowers and gardens on the context and tourism potential. Ornam. Hortic. 2020, 26, 121-133. [CrossRef]

40. Khatami, F.; Sorano, E.; Bechis, M. Assessment of food heritage to improve virtuous cycles. J. Cult. Herit. Manag. Sustain. Dev. 2020, 11, 280-296. [CrossRef]

41. Tagiya, M.; Sinha, S. Horticulture tourism: Synergy for Sustainable Rural development. Prospect for Arunachal Pradesh. Prospect. Arunachal Pradesh 2016, 7, 133-140.

42. Kulczyk, S.; Kordowska, M.; Duda-Gromada, K. Challenges to Urban Gastronomy: Green and Blue Spaces. In Gastronomy and Urban Space: Changes and Challenges in Geographical Perspective; Kowalczyk, A., Derek, M., Eds.; Springer Nature: Cham, Switzerland, 2020.

43. Krikser, T.; Piorr, A.; Berges, R.; Opitz, I. Urban Agriculture Oriented towards Self-Supply, Social and Commercial Purpose: A Typology. Land 2016, 5, 28. [CrossRef]

44. Rosenberg, B. The Role of Ecosystem Services for a Resilient Urban Agriculture System: Case Studies from the Stockholm Region; School of Architecture and the Built Environment, KTH Royal Institute of Technology: Stockholm, Sweden, 2021.

45. Winkler, B.; Maier, A.; Lewandowski, I. Urban Gardening in Germany: Cultivating a Sustainable Lifestyle for the Societal Transition to a Bioeconomy. Sustainability 2019, 11, 801. [CrossRef]

46. Langemeyer, J.; Camps-Calvet, M.; Calvet-Mir, L.; Barthel, S.; Gómez-Baggethun, E. Stewardship of urban ecosystem services: Understanding the value(s) of urban gardens in Barcelona. Landsc. Urban Plan. 2018, 170, 79-89. [CrossRef]

47. Lattuca, A.; Terrile, R.; Bracalenti, L.; Lagorio, L.; Ramos, G.; Moreira, F. Building food secure neighbourhoods in Rosario. Urban Agric. Mag. 2005, 15, 23-24.

48. Jiang, F.; Yuan, H.; Liu, S.; Cai, J. Multifunctional agrotourism in Beijing. Urban Agric. Mag. 2005, 15, $14-15$.

49. Forleo, M.B.; Benedetto, G. Creative cities of gastronomy: Towards relationship between city and countryside. Int. J. Gastron. Food Sci. 2020, 22, 100247. [CrossRef]

50. Derek, M. Nature on a Plate: Linking Food and Tourism within the Ecosystem Services Framework. Sustainability 2021, $13,1687$. [CrossRef]

51. Fusté-Forné, F. Seasonality in food tourism: Wild foods in peripheral areas. Tour. Geogr. 2019, 19, 1-21. [CrossRef]

52. Jørstad, M.; Roaldsen, I.; Ljunggren, E. Local food in tourism: A systematic literature review. J. Gastron. Tour. 2020, 4, 97-111. [CrossRef]

53. Rousta, A.; Jamshidi, D. Food tourism value: Investigating the factors that influence tourists to revisit. J. Vacat. Mark. 2020, 26, 73-95. [CrossRef]

54. Muñoz, L. Beneficios de Los Huertos Urbanos. 2020. Available online: https://www.agrohuerto.com/beneficios-de-los-huertosurbanos-para-ti-y-para-tu-ciudad/ (accessed on 1 February 2021).

55. Bertrán Arroyo, E. Análisis de gestión y valoración socio-cultural de los huertos urbanos comunitarios en la ciudad de Córdoba (España). RIVAR-Revista Iberoamericana Viticultura Agroindustria Ruralidad 2015, 2, 87-109.

56. Aires, I. De la Huerta al Plato: Restaurantes con Huerto Propio. 2020. Available online: https://www.ondacero.es/emisoras/ comunidad-madrid/madrid/audios-podcast/mas-uno-madrid/restaurantes-madrid-huerto-propio_202006255ef597643c943 20001639fef.html (accessed on 1 February 2021).

57. Horcajo, D. El Huerto del Hotel Wellington. Un Huerto Urbano muy Especial. 2019. Available online: https://www.agrohuerto. com/un-huerto-en-el-hotel-wellington/ (accessed on 1 February 2021). 
58. Chan, K.M.A.; Satterfield, T.; Goldstein, J. Rethinking ecosystem services to better address and navigate cultural values. Ecol. Econ. 2012, 74, 8-18. [CrossRef]

59. Kelly, C. Beyond 'a trip to the seaside': Exploring emotions and family tourism experiences. Tour. Geogr. 2020, 23, 1-22. [CrossRef]

60. Li, M.; Lehto, X.; Li, H. 40 years of family tourism research: Bibliometric analysis and remaining issues. J. China Tour. Res. 2020, 16, 1-22. [CrossRef]

61. Schänzel, H.A.; Yeoman, I. Trends in family tourism. J. Tour. Futures 2015, 1, 141-147. [CrossRef]

62. Ugolini, F.; Massetti, L.; Calaza-Martínez, P.; Cariñanos, P.; Dobbs, C.; Ostoić, S.K.; Marin, A.M.; Pearlmutter, D.; Saaroni, H.; Šaulienè, I.; et al. Effects of the COVID-19 pandemic on the use and perceptions of urban green space: An international exploratory study. Urban For. Urban Green. 2020, 56, 126888. [CrossRef] [PubMed]

63. Fusté-Forné, F.; Michael, N. Limited tourism: Travel bubbles for a sustainable future. J. Sustain. Tour. 2021, 3, 1-18. [CrossRef]

64. Hillman, W.; Radel, K. Qualitative Methods in Tourism Research; Channel View Publications: Bristol, UK, 2018.

65. Roulston, K.; DeMarrais, K.; Lewis, J.B. Learning to interview in the social sciences. Qual. Inq. 2003, 9, 643-668. [CrossRef]

66. Ren, C. Qualitative research, tourism. In Encyclopedia of Tourism; Series 1-4; Jafari, J., Xiao, H., Eds.; Springer Publishing Company: Cham, Switzerland, 2016.

67. Holstein, J.A.; Gubrium, J.F. Interviewing as a Form of Narrative Practice. In Qualitative Research; Silverman, D., Ed.; Sage Publications: Thousand Oaks, CA, USA, 2020.

68. Nunkoo, R. Handbook of Research Methods for Tourism and Hospitality Management; Edward Elgar Publishing: Cheltenham, UK, 2018.

69. Ram, Y.; Hall, C.M. Length of family vacations, children's age and parenting style. Anatolia 2015, 26, 476-479. [CrossRef]

70. Zhang, C.H.; Zhang, H. Research on the Effect of Children's Ages on Family Tourism Decision. J. Qufu Norm. Univ. 2009, 35, 102-110.

71. UNICEF. Bienestar Infantil en España. Indicadores Básicos Sobre la Situación de los Niños y Niñas en Nuestro País; UNICEF: Madrid, Spain, 2016.

72. Wojciechowska, K. Preparing a preschool age child for tourism and local history exploration. Ekonomiczne Problemy Turystyki 2015, 31, 75-86. [CrossRef]

73. Denzin, N.K.; Lincoln, Y.S. Strategies of Qualitative Inquiry; Sage Publications: Thousand Oaks, CA, USA, 1999.

74. Walters, T. Using thematic analysis in tourism research. Tour. Anal. 2016, 21, 107-116. [CrossRef]

75. Armstrong, D. A survey of community gardens in upstate New York: Implications for health promotion and community development. Health Place 2000, 6, 319-327. [CrossRef]

76. Llobera Serra, P. Horticultura urbana: La red de huertos urbanos comunitarios de Madrid. Ambienta Revista Ministerio Medio Ambiente 2014, 107, 120-128.

77. Budruk, M.; Thomas, H.; Tyrrell, T. Urban green spaces: A study of place attachment and environmental attitudes in India. Soc. Nat. Resour. 2009, 22, 824-839. [CrossRef]

78. UNWTO. UNWTO Recommendations on Urban Tourism; UNWTO: Madrid, Spain, 2019.

79. Valencia Castro, J.J.; Neira Seijo, X.X.; Cuesta García, T.S.; Cancela Barrio, J.J. Estrategias para la implantación de huertos urbanos: Aplicación a la ciudad de Ourense. In Actas IX Congreso Internacional de Ingeniería de Proyectos; Universidad de Málaga: Málaga, Spain, 2005; pp. 398-408.

80. Hou, J. Governing urban gardens for resilient cities: Examining the 'Garden City Initiative' in Taipei. Urban Stud. 2020, 57, 1398-1416. [CrossRef]

81. Fusté, M.; Fusté-Forné, F. Enseñando Gastronomía: Descubrir los alimentos en la etapa infantil (Teaching Gastronomy: The discovery of food in childhood education). Revista Eletrônica Educação 2019, 13, 1221-1234. [CrossRef]

82. Donald, B. Food systems planning and sustainable cities and regions: The role of the firm in sustainable food capitalism. Reg. Stud. 2008, 42, 1251-1262. [CrossRef]

83. Hui, S.C.M. Green roof urban farming for buildings in highdensity urban cities. In Proceedings of the World Green Roof Conference, Hainan, China, 18-21 March 2011.

84. Ackerman, K. The Potential for Urban Agriculture in New York City: Growing Capacity, Food Security, and Green Infrastructure; Columbia University: New York, NY, USA, 2011.

85. Haywood, K.M.; Muller, T.E. The urban tourist experience: Evaluating satisfaction. Hosp. Educ. Res. J. 1988, 12, 453-459. [CrossRef]

86. Fusté-Forné, F. Street food in New York City: Perspectives from a holiday market. Int. J. Gastron. Food Sci. 2021, 24, 100319. [CrossRef]

87. Tseng, M.L.; Lin, C.W.R.; Sujanto, R.Y.; Lim, M.K.; Bui, T.D. Assessing sustainable consumption in packaged food in Indonesia: Corporate communication drives consumer perception and behavior. Sustainability 2021, 13, 8021. [CrossRef] 